\title{
The chemical properties of soil for alfalfa production after biofertiliser application ${ }^{1}$
}

\author{
Atributos químicos no solo e produção de alfafa sob \\ doses de biofertilizante
}

\author{
Rodrigo Luis Lemes²; Cecílio Viega Soares Filho ${ }^{3}$; \\ Manoel Garcia Neto ${ }^{3}$; Reges Heinrichs ${ }^{4}$
}

\begin{abstract}
The objective of this study was to evaluate the use of biofertilisers for the production of alfalfa shoot, root and nodule dry matter, and also, to evaluate the chemical properties of the soil. This study was conducted in the greenhouse of the Support Department, Animal Production and Health, Faculty of Veterinary Medicine/UNESP, Araçatuba - SP, from May to October 2010. The experimental design was completely randomised with six biofertiliser doses $\left(0,25,50,100,200\right.$ and $\left.400 \mathrm{~m}^{3} \mathrm{ha}^{-1}\right)$ and five replicates. The biofertiliser doses were the primary treatments and the cuts (five) were subplots. The cuts were performed, on average, every 27 days at $10 \mathrm{~cm}$ above the soil. At the end of the experiment, the roots, nodules and soil from all experimental units were collected for chemical analysis. We observed a linear increase in dry matter production of the shoots relative to the doses studied. The dry matter production of the roots and nodules was not significantly different. The chemical properties of the soil significantly improved for calcium and magnesium as well as the sum of bases and base saturation with biofertiliser application. Biofertilisers can be used for agricultural production and favourably alter the soil characteristics.
\end{abstract}

Key words: Biofertiliser, Medicago sativa, nitrogen, nodules, roots

\section{Resumo}

O objetivo deste trabalho foi avaliar o uso de doses de biofertilizante na produção de matéria seca da parte aérea, raízes e nódulos da alfafa, e os atributos químicos do solo. O experimento foi realizado em casa de vegetação do Departamento de Apoio, Produção e Saúde Animal da Faculdade de Medicina Veterinária/UNESP, Campus de Araçatuba - SP, de maio a outubro de 2010. O delineamento experimental foi inteiramente ao acaso, sendo seis doses de biofertilizante $(0,25,50,100,200$ e 400 $\left.\mathrm{m}^{3} \mathrm{ha}^{-1}\right)$ e cinco repetições. As doses de biofertilizante foram consideradas como tratamentos principais e os cortes (cinco) como subparcelas. Os cortes foram realizados, em média, a cada 27 dias, a $10 \mathrm{~cm}$ de altura do solo. Ao final do experimento foram coletadas as raízes, nódulos e o solo de todas as unidades experimentais para análise química. Foi observado aumento linear na produção de matéria seca da parte aérea em relação as doses estudadas. A produção de matéria seca de raiz e nódulos não apresentaram diferença significativa. Para os atributos químicos do solo ocorreu resposta positiva para os teores de cálcio, magnésio, soma de bases e saturação de bases com a aplicação do biofertilizante. O biofertilizante pode ser utilizado como insumo na agropecuária para melhorar a produção e alterar favoravelmente os atributos do solo.

Palavras-chave: Chorume bovino, Medicago sativa, nitrogênio, nódulos, raízes

1 Projeto financiado pela FAPESP. Processo no 2010/09446-3.

2 Zootecnista, M.e em Ciência Animal, Faculdade de Medicina Veterinária, UNESP, Campus de Araçatuba, SP. E-mail: rllemes@, hotmail.com

3 Profs Drs. da UNESP, Faculdade de Medicina Veterinária, Campus de Araçatuba, SP. E-mail: cecilio@fmva.unesp.br; mgarcia@ fmva.unesp.br

4 Prof. Dr. da UNESP, Curso de Zootecnia, CEDRAC/UNESP, Campus de Dracena, SP. E-mail: reges@dracena.unesp.br

* Author for correspondence 


\section{Introduction}

Brazil is an important producer in the meat and milk sectors, particularly because of the low cost of production as a result of appropriate pasture usage. This makes the country internationally competitive in these markets.

To maximise milk production, it is necessary to supplement with protein and energy. The administration of concentrated feed to dairy cows is a very efficient nutritional practice; however, it considerably raises production costs (VILELA et al., 1996). Therefore, forage legumes have been used as a low cost alternative to supplement animal feed.

Alfalfa (Medicago sativa L.) is an important alternative, particularly because of it nutritional quality, good productivity, ability to fix atmospheric nitrogen $\left(\mathrm{N}_{2}\right)$ and high palatability (MOREIRA; et al., 2007; RODRIGUES; CAMERÓN; VILELA, 2008 ), in addition to the low seasonality in forage production.

Moreover, the intensification and concentration of production contribute to the accumulation of waste, termed biofertilisers. The production of waste during milk production can become a serious economic, environmental or legal problem if not correctly managed.

The environmental costs of production are high, and in some regions of the country, the level of environmental pollution is equal to or exceeds international values. Much of the waste from pigs, poultry and cattle is released into nature where it becomes a large source of pollution (RTS, 2009).

Sustainable management has been recommended as a method to reduce the problems caused by the accumulation of animal waste on farms. The use of animal waste as an input in agricultural production is an efficient manner to use this material because it not only reduces pollution and potential production costs but also improves soil quality.

The use of biofertilisers for legumes remains questionable for plant nutrition, particularly for nitrogen and its influence on the productive response of the plant.

With dwindling natural resources and the indiscriminate use of fertilisers, which causes contamination of the environment and rising production costs, it is important to evaluate the response of alfalfa to the application of biofertilisers.

Therefore, the shoot, root, and nodule dry matter and the chemical properties of the soil with increasing doses of biofertiliser were evaluated.

\section{Materials and Methods}

The study was conducted from 19/04/2010 to $21 / 10 / 2010$ in a greenhouse with a plastic cover at the Support Department, Animal Production and Health, Faculty of Veterinary Medicine Araçatuba / UNESP, Araçatuba SP, at a $415 \mathrm{~m}$ altitude.

In one area of the Support Department pasture, the Animal Production and Health service collected soil, which was classified as Typical at a depth of $0-20 \mathrm{~cm}$. The soil was passed through a sieve with a four millimetre mesh, and a sample was removed for analysis. The soil sample had the following chemical characteristics: $\mathrm{P}=3 \mathrm{mg} \mathrm{dm}{ }^{-3}, \mathrm{OM}=17$ $\mathrm{g} \mathrm{dm}^{-3}, \mathrm{pH}$ in $\mathrm{CaCl}_{2}=4.6, \mathrm{~K}=1.6 \mathrm{mmol} \mathrm{dm}^{-3}, \mathrm{Ca}$ $=13 \mathrm{mmol} \mathrm{dm}^{-3}, \mathrm{Mg}=6 \mathrm{mmol} \mathrm{dm}{ }^{-3}, \mathrm{H}+\mathrm{Al}=34$ mmol dm ${ }^{-3}$, sum of bases $=20.6 \mathrm{mmol} \mathrm{dm}^{-3}$, cation exchange capacity $=54.6 \mathrm{mmol} \mathrm{dm}^{-3}$ and base saturation $=37.7 \%$.

The base saturation increased to $80 \%$ (WERNER et al., 1997) with the application of $\mathrm{CaCO}_{3}$ and $\mathrm{MgCO}_{3}$, with an i.e. reagent at a 3:1 ratio. The soil was then incubated for 30 days in the vessel, with the humidity maintained at $80 \%$ of the field capacity.

After the incubation period, the soil was dried again for seven days. The soil from each pot was placed in plastic trays and other nutrients were added as follows: $\mathrm{Ca}\left(\mathrm{H}_{2} \mathrm{PO}_{4}\right)_{2}, 200 \mathrm{mg} \mathrm{dm}{ }^{-3} \mathrm{P} ; \mathrm{K}_{2} \mathrm{SO}_{4}, 150$ $\mathrm{mg} \mathrm{dm}{ }^{-3} \mathrm{~K}$ and $61.53 \mathrm{mg} \mathrm{dm}{ }^{-3} \mathrm{~S} ; \mathrm{H}_{3} \mathrm{BO}_{3}, 0.5 \mathrm{mg}$ 
$\mathrm{dm}^{-3} \mathrm{~B} ; \mathrm{CuSO}_{4}, 1.0 \mathrm{mg} \mathrm{dm}{ }^{-3} \mathrm{Cu} ; \mathrm{H}_{2} \mathrm{MoO}_{4}, 0.1 \mathrm{mg}$ $\mathrm{dm}^{-3} \mathrm{Mo} ; \mathrm{MnSO}_{4}, 3 \mathrm{mg} \mathrm{dm}{ }^{-3} \mathrm{Mn}$; and $\mathrm{ZnSO}_{4}, 2.0$ $\mathrm{mg} \mathrm{dm}{ }^{-3} \mathrm{Zn}$.

The biofertiliser used in the experiment originated from residual manure plus urine from a cowshed dairy after anaerobic fermentation in a digester. The chemical characteristics were as follows: $0.300 \mathrm{~g} \mathrm{~L}^{-1} \mathrm{~N}, 0.057 \mathrm{~g} \mathrm{~L}^{-1} \mathrm{P}, 0.188 \mathrm{~g} \mathrm{~L}^{-1} \mathrm{~K}$; $0.105 \mathrm{~g} \mathrm{~L}^{-1} \mathrm{Ca}, 0.057 \mathrm{~g} \mathrm{~L}^{-1} \mathrm{Mg}, 1 \mathrm{mg} \mathrm{L}^{-1}$ of $\mathrm{Mn}, 1$ $\mathrm{mg} \mathrm{L}{ }^{-1} \mathrm{Fe}$ and $1 \mathrm{mg} \mathrm{L}^{-1} \mathrm{Zn}$.

The experimental design was completely randomised with six biofertiliser doses $(0,25,50$, 100, 200 and $400 \mathrm{~m}^{3} \mathrm{ha}^{-1}$ ) and five replications for a total of 30 experimental units. The biofertiliser was applied three times so as not to saturate the soil with high doses of biofertiliser. The first application was coupled with sowing, the second application was performed 30 days after the first application, and the third application occurred nine days after the second fertiliser application and 20 days before the first cut.

In May 2010, the alfalfa was seeded, and after 15 days, the plants were thinned, leaving only five uniform plants per pot. Five cuts $10 \mathrm{~cm}$ above the soil were performed when the plants were $10 \%$ flowering. These cuts occurred on 19/07/2010 (59 days after sowing), 09/08/2010 (21 days of age), 02/09/2010 (24 days of age), 24/09/2010 (22 days of age) and 21/10/2010 (27 days of age).

The shoot was cut, wrapped in paper bags, and then placed in an oven at $65{ }^{\circ} \mathrm{C}$ to dry the shoot to a constant weight, according to the method of Silva and Queiroz (2002). After five cuts, the roots were collected, washed in a mesh sieve, and separated from the nodules, which were dried and weighed.

The nodules were placed in paper bags and dried in an oven with forced air circulation at $65{ }^{\circ} \mathrm{C}$ for 72 hours to determine the dry weight of the nodules. At the end of the experiment, the soil samples were analysed according to the method of Raij et al. (2001).

The data from the soil analysis and the shoot, root and nodule dry matter (DM) were tested for normality of errors and homogeneity of variances, and statistical analyses were performed using SAS (Statistical Analysis System, version 9.1) in the GLM model for the plot over time, with the doses of biofertiliser as the primary treatment and the cuts as the subplot. The results were analysed by an ANOVA and the Duncan test for multiple comparisons of the means at the 5\% significance level. Regression analyses were performed according to the doses of biofertiliser (PIMENTEL-GOMES; GARCIA, 2002), and regression analysis of the nonlinear models was performed as follows: $y=f(\beta, x)+\varepsilon$ (VEDENOV; PESTI, 2007).

\section{Results and Discussion}

The production of alfalfa shoot dry matter was significantly different between the biofertiliser doses studied. It was determined that the best equation was a linear model within the range studied (Figure 1).

This increase in the alfalfa dry matter yield may be explained by the extra amount of nutrients provided to the plants, such as nitrogen, potassium, calcium and sulphur present in the biofertiliser, as well as an improvement in the chemical properties of the soil and the likely stimulation of microorganisms in the soil.

Figure 1. Production of dry matter from alfalfa fertilised with biofertiliser.

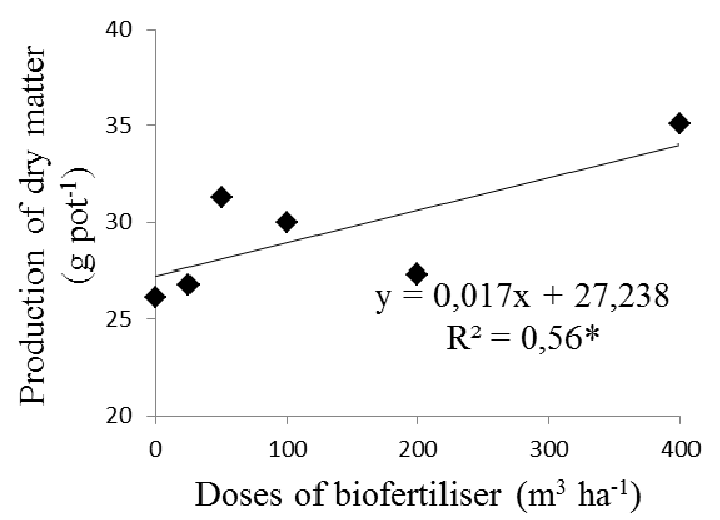

Source: Elaboration of the authors. 
These results are consistent with Schmitt, Sheaffer and Randall (1993). They found that adding pig manure (28, 56 and $\left.112 \mathrm{t} \mathrm{ha}^{-1}\right)$ and mineral fertiliser during a field experiment caused a significant increase in the alfalfa dry matter yield harvested from manure-treated plants compared to control-treated plants.

The dry matter production of the alfalfa roots and nodules were not significantly different between the biofertiliser doses (Table 1).

Table 1. Medium dry matter of alfalfa roots and nodules based on the biofertiliser dose.

\begin{tabular}{|c|c|c|c|c|}
\hline \multirow{2}{*}{ Sources of variation } & \multicolumn{4}{|c|}{ Mean squares } \\
\hline & \multicolumn{2}{|c|}{ DM Roots } & \multicolumn{2}{|c|}{ DM Nodules } \\
\hline Doses of Biofertiliser & 4.55 & ns & 0.05 & ns \\
\hline Standard error of the mean & 8.28 & & 0.13 & \\
\hline \multirow[t]{2}{*}{ Coefficient of Variation (\%) } & 15.48 & & 32.49 & \\
\hline & \multicolumn{3}{|c|}{ - } & \\
\hline Average & 18.58 & & 1.12 & \\
\hline Standard Deviation & \pm 0.95 & & \pm 0.10 & \\
\hline
\end{tabular}

ns = Not significant. Doses of biofertiliser 0 a $400 \mathrm{~m}^{3} \mathrm{ha}^{-1}$.

Source: Elaboration of the authors.

These results are consistent with Russelle et al. (2007). They performed an experiment in a nitrogen rich area in which they used an alfalfa cultivar with the ability to fix nitrogen and an alfalfa cultivar that was unable to fix atmospheric nitrogen through symbiosis. They observed no difference in the production and distribution of root dry matter between the two cultivars. The authors also found no correlation between the amount of root dry matter produced and the amount of $\mathrm{N}$ mineralised in the soil.

Oliveira et al. (2004) found a similar number of nodules for different cultivars, but their field study found a greater number of nodules in the treatment group without fertilisation compared to the group that received nitrogen fertilisation. This may be associated with the inhibitory effects of mineral fertilisers that shorten the life of the cultivar and the quality of the protein in the dry matter (CIHACEK, 1994).
Gomes et al. (2002) studied the lime and Ca:Mg ratios in alfalfa and found differences in the number of nodules per pot. They obtained the best results with the highest doses $\left(7.2 \mathrm{tha}^{-1}\right)$ of limestone, with no significant difference for $\mathrm{Ca}: \mathrm{Mg}$. The increase in the number of nodules was related to the increase in the $\mathrm{N}$ content in the dry matter of the shoots. In the present experiment, the soil was corrected and may have contributed to the observation that there was no difference in the dry weight of nodules and that the organic biofertiliser applied did not cause a reduction in nodulation.

There was no significant difference between the doses of biofertiliser for the $\mathrm{pH}$, calcium $(\mathrm{Ca})$, magnesium $(\mathrm{Mg})$, sum of bases (SB) and base saturation (V\%) (Table 2 and Figure 2). For $\mathrm{Ca}$, a quadratic effect was observed, whereas for $\mathrm{Mg}, \mathrm{SB}$, $\mathrm{V}$ and boron (B), a linear effect was observed. 
Table 2. Means and standard deviations of the chemical properties of the soil depending on the biofertiliser application.

\begin{tabular}{|c|c|c|c|c|c|c|c|}
\hline \multirow{3}{*}{$\begin{array}{l}\text { Sources of } \\
\text { variation } \\
\text { Doses of } \\
\text { Biofertiliser }\end{array}$} & \multicolumn{7}{|c|}{ Mean squares } \\
\hline & $\mathrm{pH}\left(\mathrm{CaCl}_{2}\right)$ & \multicolumn{2}{|l|}{$\mathrm{OM}$} & $\mathrm{P}$ & $\mathrm{H}+\mathrm{Al}$ & $\mathrm{K}$ & CEC \\
\hline & $0.04 *$ & 11.50 & ns & $140.41 \mathrm{~ns}$ & $17.23 \mathrm{~ns}$ & 0.07 & 29.99 \\
\hline Error & 0.02 & 10.14 & & 105.87 & 7.12 & 0.04 & 12.89 \\
\hline \multirow[t]{2}{*}{$\begin{array}{l}\text { Coefficient of } \\
\text { Variation }(\%)\end{array}$} & 2.54 & 15.92 & & 16.20 & 9.37 & 28.46 & 6.40 \\
\hline & & $\mathrm{g} \mathrm{dm}^{-3}$ & & $\mathrm{mg} \mathrm{dm}^{-3}$ & & $\mathrm{mmol}_{\mathrm{c}} \mathrm{dm}^{-3}$ & \\
\hline Average & 5,03 & 20,00 & & 63,49 & 28,48 & 0,69 & 56,07 \\
\hline $\begin{array}{l}\text { Standard } \\
\text { Deviation }\end{array}$ & \pm 0.09 & \pm 1.51 & & \pm 5.30 & \pm 1.85 & \pm 0.12 & \pm 2.44 \\
\hline
\end{tabular}

${ }_{\mathrm{ns}}=$ Not significant. $*$ Significant at 0.05 by $\mathrm{F}$ test. $\mathrm{OM}=$ Organic matter and $\mathrm{CEC}=$ cation exchange capacity. Doses of biofertiliser 0 a $400 \mathrm{~m}^{3} \mathrm{ha}^{-1}$.

Source: Elaboration of the authors.

Figure 2. Levels of calcium (a) and magnesium (b) in the soil cultivated with alfalfa according to the doses of biofertiliser.

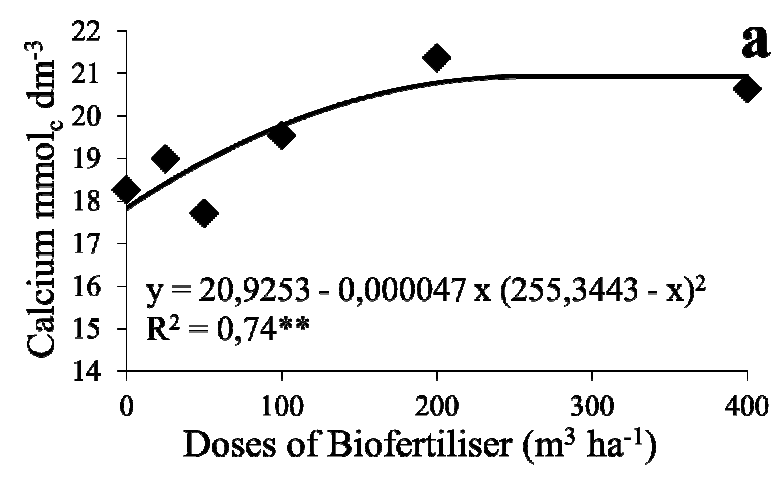

Source: Elaboration of the authors.

The $\mathrm{pH}$ varied from 4.94 to 5.19 , with the higher dose of $100 \mathrm{~m}^{3} \mathrm{ha}^{-1}$ biofertiliser; however, the $\mathrm{pH}$ was not significantly different for biofertiliser doses of 0 and $400 \mathrm{~m}^{3} \mathrm{ha}^{-1}$. Maintenance of the $\mathrm{pH}$ in all treatments was positive because mineral fertilisers containing $\mathrm{N}$ typically decrease the $\mathrm{pH}$ with increasing doses of fertiliser.

Although the $\mathrm{pH}$ was different according to the F test (Table 2), it did not differ in the regression analysis and did not fit into linear and quadratic equations; therefore, it cannot properly explain the

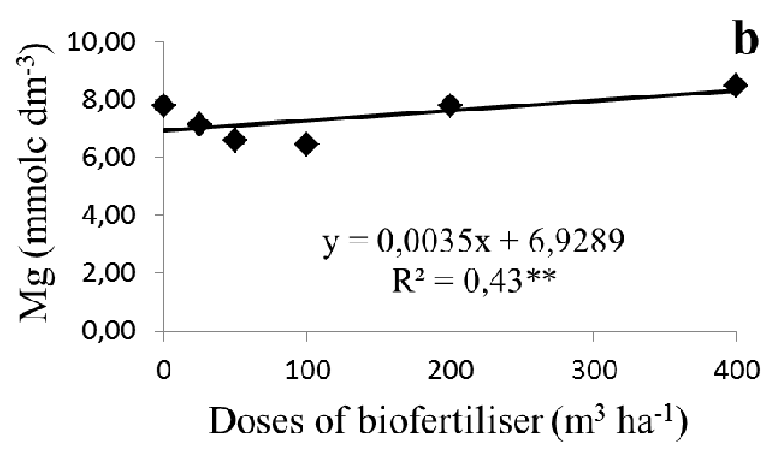

biological experiments. The average value is shown with the standard deviation.

The concentration of $\mathrm{Ca}$ is quadratic, and $255 \mathrm{~m}^{3}$ $\mathrm{ha}^{-1}$ biofertiliser provided the largest concentration of this nutrient in the soil (Figure 2a). The Mg concentration in the soil was linear and responded to dose of $400 \mathrm{~m}^{3} \mathrm{ha}^{-1}$ (Figure 2b).

The $\mathrm{Ca}$ and $\mathrm{Mg}$ were similar, although the higher doses of biofertiliser showed the highest concentrations of these nutrients in the soil at the end of the experiment. For doses of 200 and $400 \mathrm{~m}^{3}$ 
ha $^{-1}$, the concentration of $\mathrm{Ca}$ was 21.37 and 20.63 $\mathrm{mmol} \mathrm{dm}{ }^{-3}$ and the concentration of $\mathrm{Mg}$ was 7.80 and $8.54 \mathrm{mmol} \mathrm{dm}^{-3}$, respectively, resulting in a $\mathrm{Ca}: \mathrm{Mg}$ of approximately to $3: 1$.

It is important to maintain the ratio of $\mathrm{Ca}: \mathrm{Mg}$ because in a study with different $\mathrm{Ca}: \mathrm{Mg}$ ratios, Gomes et al. (2002) observed a negative effect with excess $\mathrm{Mg}$ for the dry matter yield of alfalfa 20 days after sowing.

Moreira et al. (1999) found that a 4:1 ratio of $\mathrm{Ca}: \mathrm{Mg}$ showed the best efficiency for the nodulation of alfalfa. Treatments of 100 and $200 \mathrm{~m}^{3} \mathrm{ha}^{-1}$ were nearly at a 3:1 ratio. Lloveras et al. (2004) applied swine manure (25 and $\left.50 \mathrm{~m}^{3} \mathrm{ha}^{-1}\right)$ to alfalfa and found a significant increase $(\mathrm{P}>0.05)$ in the $\mathrm{Mg}$ content of the soil when $50 \mathrm{~m}^{3} \mathrm{ha}^{-1}$ pig manure was applied.
If we compare the concentration of $\mathrm{Ca}$ and $\mathrm{Mg}$ in the soil at the beginning of the experiment (13:06 mmol dm${ }^{-3}$, respectively), we see that all treatments increased in concentration with the application of biofertiliser; however, the concentration was much higher for the 200 and $400 \mathrm{~m}^{3} \mathrm{ha}^{-1}$ treatments (Figure 2). This increase is important because according to Moreira et al. (2008), alfalfa most likely absorbs more $\mathrm{Ca}$ and $\mathrm{Mg}$. Additionally, according to Honda and Honda (1990), the removal of Ca was $224 \mathrm{~kg}$ $\mathrm{ha}^{-1}$ and $45 \mathrm{~kg} \mathrm{Mg} \mathrm{ha}{ }^{-1}$, which is much higher than other crops, such as cotton, corn and soybean.

The sum of bases behaved similarly to $\mathrm{Ca}$ and $\mathrm{Mg}$ (Figure 3a). The $\mathrm{SB}$ is expressed in mmol $\mathrm{dm}^{-3}$ and is the sum of $\mathrm{Ca}, \mathrm{Mg}$, potassium $(\mathrm{K})$, and sometimes sodium $(\mathrm{Na})$ in the exchangeable form. The increased $\mathrm{Ca}$ and $\mathrm{Mg}$ for the largest doses of biofertiliser also increased the SB.

Figure 3. Levels of sum of bases (SB) (a) and saturation of bases (b) in soil cultivated with alfalfa according to the doses of biofertiliser.

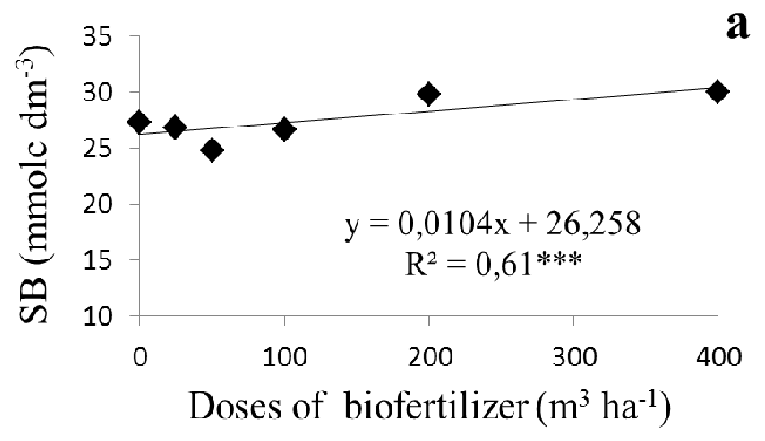

Source: Elaboration of the authors

The (V\%) showed higher values with increasing doses of biofertiliser, and the values ranged from 45 to $52 \%$ of saturation (Figure $3 b$ ) at the end of the experiment. This increase in base saturation, although not ideal for the cultivation of alfalfa, was beneficial for a greater crop yield because $\mathrm{V}=80 \%$ according to Werner et al. (1997).

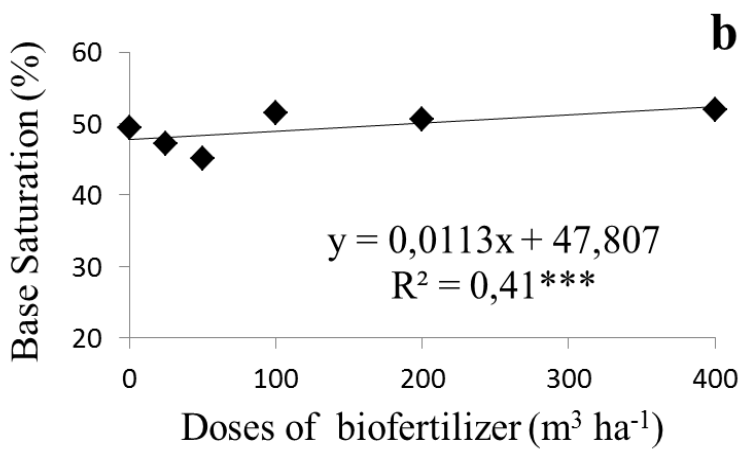

However, Moreira et al. (1999) performed an experiment with two doses of lime, which were sufficient to raise the base saturation to $80 \%$ (3.9 $\left.\mathrm{t} \mathrm{ha}^{-1}\right)$ and found significantly higher production in the treatment with the highest dose.

The organic matter (OM), phosphorus (P), potential acidity $(\mathrm{H}+\mathrm{Al})$, potassium $(\mathrm{K})$ and 
cation exchange capacity (CEC) showed no significant difference $(\mathrm{P}>0.05)$ between the doses of biofertiliser applied (Table 2). This may have occurred because despite the large volume used for some treatments, the biofertiliser had a very high concentration of solids; therefore, even the largest doses were sufficient to significantly alter these attributes. However, comparing the initial data of the soil with the average score at the end of the experiment showed an improvement in the various chemical attributes, such as OM, P and CEC.

The concentration of $\mathrm{P}$ in a dose of $400 \mathrm{~m}^{3} \mathrm{ha}^{-1}$ of biofertiliser is significantly different $(\mathrm{P}<0.05)$ from the control, with a $27 \%$ increase, but it did not differ from the other doses (Table 2). In an experiment with pig manure, Salmerón et al. (2010) observed a $21 \%$ increase in the $\mathrm{P}$ concentration compared to the control in the first $30 \mathrm{~cm}$ of soil. The $\mathrm{P}$ concentration should be monitored carefully to avoid contamination of the underground water reserves according to Werner et al. (1997).

The $\mathrm{K}$ concentration in the soil decreased by $43 \%$ on average compared to the beginning of the experiment. According to Rassini (1998), K is the most necessary nutrient for alfalfa, and when neglected, there is a loss of vigour and lower longevity. In this experiment, $\mathrm{K}$ was not applied after the cuts, which should have led to the extraction of $\mathrm{K}$ by the crop during the evaluation period.

The concentrations of the micronutrients iron $(\mathrm{Fe})$, manganese $(\mathrm{Mn})$ and zinc $(\mathrm{Zn})$ in the soil after the last cut did not differ significantly (Table 3). The concentration of $\mathrm{B}$ decreased with increasing doses of biofertiliser (Figure 4) and most likely occurred with increased extraction yield of the DM with higher doses of biofertiliser. These data are consistent with Moreira et al. (2000), who tested various Ca:Mg ratios, and Werner et al. (1997), who required only a pound of boron per ha.
Figure 4. Boron content in the soil cultivated with alfalfa according to increasing doses of biofertiliser.

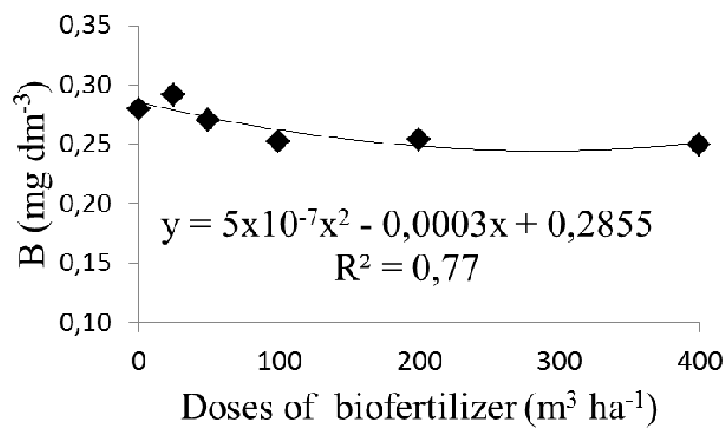

Source: Elaboration of the authors.

The concentrations of copper $(\mathrm{Cu})$ and $\mathrm{Fe}$ in the soil at the end of the experiment (Table 3) were similar to Moreira et al. (2000). It is not necessary to fertilise with $\mathrm{Cu}$ for alfalfa (WERNER et al., 1997). Lloveras et al. (2004) applied swine manure (25 and $50 \mathrm{~m}^{3} \mathrm{ha}^{-1}$ ) to alfalfa and found similar concentrations of $\mathrm{Cu}$; however, there was no significant increase after manure treatment for poor soil after two years. Additionally, the concentrations of Fe were lower than this study, and showed a significant increase with a treatment of $50 \mathrm{~m}^{3} \mathrm{ha}^{-1}$ compared to the control soil fertility, which was slightly higher.

The $\mathrm{Mn}$ and $\mathrm{Zn}$ at the end of the experiment were well below the levels observed by Lloveras et al. (2004). Moreover, Moreira et al. (2000) also found no difference. However, according to Werner et al. (1997), these levels are adequate for the establishment of alfalfa, and it is not necessary to fertilise with $\mathrm{Zn}$.

\section{Conclusions}

The alfalfa responded linearly up to a dose of $400 \mathrm{~m}^{3} \mathrm{ha}^{-1}$ of biofertiliser for the total production of dry matter. The $\mathrm{Ca}, \mathrm{Mg}, \mathrm{SB}$ and $\mathrm{V} \%$ of the soil were positively influenced by the use of biofertilisers. 


\section{References}

CIHACEK, L. J.Alfalfa nutrient needs and fertilization. In: WORKSHOP SOBRE O POTENCIAL FORRAGEIRO DA ALFAFA (Medicago sativa L.) NOS TRÓPICOS, 1., Juiz de Fora, 1994. Anais... Juiz de Fora: EMBRAPA, CNPGL, 1994. p. 93-97.

GOMES, F. T.; BORGES, A. C.; NEVES, J. C. L.; FONTES, P. C. R. Nodulação, fixação, de nitrogênio e produção de matéria seca de alfafa em resposta a doses de calcário, com diferentes relações cálcio: magnésio. Ciência Rural, Santa Maria, v. 32, n. 6, p. 925-930, 2002.

HONDA, C. S.; HONDA, A. M. Cultura da alfafa. Cambará: IARA Artes Gráficas, 1990. 245 p.

LLOVERAS, J.; ARA'N, M.; VILLAR, P.; BALLESTA, A.; ARCAYA, A.; VILANOVA, X.; DELGADO, I.; MUÑOZ, F. Effect of swine slurry on alfalfa production and on tissue and soil nutrient concentration. Agronomy Journal, Madison, v. 96, n. 4, p. 986-991, 2004.

MOREIRA, A.; BERNARDI, A. C. C.; RASSINI, J. B. Correção do solo, estado nutricional e adubação da alfafa. In: FERREIRA, R. P. (Ed.). Cultivo e utilização da alfafa nos trópicos. Brasília: EMBRAPA, 2008, p. 37-51.

MOREIRA, A.; BERNARDI, A. C. C.; RASSINI, J. B.; FERREIRA, R. de P.; OLIVEIRA, P. P. A. Fertilidade do solo e estado nutricional da alfafa cultivada nos trópicos. São Carlos: Embrapa Pecuária Sudeste, 2007. 40 p. (Embrapa Pecuária Sudeste. Documentos, 67).

MOREIRA, A.; CARVALHO, J. G.; EVANGELISTA, A. R. Influência da relação cálcio:magnésio do corretivo na nodulação, produção e composição mineral da alfafa. Pesquisa Agropecuária Brasileira, Brasília, v. 34, n. 2, p. 249-255, 1999.

MOREIRA, A.; CARVALHO, J. G.; MORAES, L. A. C.; SALVADOR, J. O. Efeito da relação cálcio e magnésio do corretivo sobre micronutrientes na alfafa. Pesquisa Agropecuária Brasileira, Brasília, v. 35, n. 10, p. 20512006, 2000 .

OLIVEIRA, W. S.; OLIVEIRA, P. P. A.; DUARTE, F. R. S.; TSAI, S. M. Alfalfa yield and quality as function of nitrogen fertilization and symbiosis with Sinorhizobium meliloti. Scientia Agricola, Piracicaba, v. 61, p. 433-438, 2004.

PIMENTEL-GOMES, F.; GARCIA, C. H. Estatística aplicada a experimentos agronômicos e florestais: exposição com exemplos e orientações para uso de aplicativos. Piracicaba: FEALQ, 2002. 309 p.

RAIJ, V. B; ANDRADE, J. C.; CANTARELLA, H.;
QUAGGIO, J. A. (Ed.). Análise química para avaliação da fertilidade de solos tropicais. Campinas Instituto Agronômico de Campinas, 2001. 284 p.

RASSINI, J. B. Alfafa (Medicago sativa L.): estabelecimento e cultivo no Estado de São Paulo. São Carlos: Embrapa Pecuária Sudeste, 1998. 27 p. (Embrapa Pecuária Sudeste. Circular técnica, 15).

REDE DE TECNOLOGIA SUSTENTÁVEL - RTS. Gestão de dejetos animais passa por expansão. 2009. Disponível em: <http://rts.ibict.br/noticias/destaque-2/ imagens/gestao-de-dejetos-animais-passa-porexpansao $>$. Acesso em: 03 jun. 2011.

RODRIGUES, A. A.; CAMERÓN, E. A.; VILELA, D. Utilização da Alfafa em pastejo para alimentação de vacas leiteiras. In: FERREIRA, R. P. (Ed.). Cultivo e utilização da alfafa nos trópicos. Brasília: EMBRAPA, 2008, p. 361-392.

RUSSELLE, M. P.; LAMB, J. F. S.; TURYK, N. B.; SHAW, B. H.; PEARSON, B. Managing nitrogen contaminated soils: Benefits of $\mathrm{N}_{2}$-fixing alfalfa. Agronomy Journal, Madison, v. 99, n. 3, p. 738-746, 2007.

SALMERÓN, M.; CAVERO. J.; DELGADO, I.; ISLA, R. Yield and environmental effects of summer pig slurry applications to irrigated alfalfa under mediterranean conditions. Journal of Production Agriculture, Madison, WI, v. 102, n. 2, p. 559-567, 2010.

SCHMITT, M. A.; SHEAFFER, C. C.; RANDALL, G. $\mathrm{W}$. Preplant manure and commercial $\mathrm{P}$ and $\mathrm{K}$ fertilizer effects on alfalfa production. Journal of Production Agriculture, Madison, WI, v. 6, p. 385-390, 1993.

SILVA, D. J.; QUEIROZ, A. C. Análise de alimentos: métodos químicos e biológicos. 3. ed. Viçosa: UFV, 2002.

VEDENOV, D.; PESTI, G. M. A comparison of methods of fitting several models to nutritional response data. Journal of Animal Science, Champaign, v. 86, n. 2, p. 500-507, 2007.

VILELA， D.; ALVIM， M. J.; CAMPOS, O. F.; RESENDE, J. C. Produção de leite de vacas holandesas em confinamento ou em pastagem de Coast-cross. Revista Brasileira de Zootecnia, Viçosa, MG, v. 25, n. 5, p. 1228-1244, 1996.

WERNER, J. C.; PAULINO, V. T.; CANTARELLA, H.; ANDRADE, N. O.; QUAGGIO, J. A. Forrageiras. In: RAIJ, V. B.; CANTARELLA, H.; QUAGGIO, J. A.; FURLANI, A. M. C. (Ed.). Recomendação de adubação e calagem para o Estado de São Paulo. Campinas Instituto Agronômico de Campinas, 1997. p. 261-267. (Boletim, 100). 